\title{
Concepção, formulação e escrita em Os pássaros do Delta do Jacuí
}

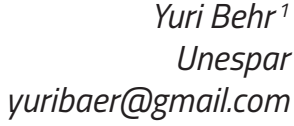




\section{Resumo}

Desde a concepção inicial até a escrita musical, existem muitos caminhos possíveis, alguns combinam técnicas originais com as de compositores renomados. Este artigo mostra como uma composição musical foi estabelecida derivando a matéria- prima obtida pela análise do canto dos pássaros, sua elaboração e as implicações na questão do tempo. Para entender como funciona, será realizada uma análise da peça Os pássaros no Delta do Jacuí, buscando os aspectos relacionados à poética, além de técnicas composicionais, com o auxílio de referências teóricas.

Palavras-chave: Tempo não linear; canto de pássaros; Orchids; escrita musical.

\section{Abstract}

From the initial conception to the musical writing, there are many possible paths, some combine original techniques together with those from renowned composers. This article shows how a musical composition has been established deriving out the raw material obtained by the analysis of birdsong, its elaboration and the implications in time issue. In order to understand how it works an analysis of the piece Os pássaros no Delta do Jacuí (The birds in Jacui's delta) will be performed looking for the aspects related to poetics likewise compositional techniques all together with the help of theoretical references.

Keywords: Non linear time; songbird; Orchids; musical writing.

Yuri Behr Kimizuka é professor colaborador na área de composição musical na Universidade Estadual do Paraná (Unespar). Doutor na área de processos de criação musical pela ECA/USP, com a tese "Modelização e pensée sauvage na prática composicional" sob a orientação do Prof. Dr. Silvio Ferraz Mello Filho. Completou um mestrado no curso de Musicologia sobre o Makrokosmos de George Crumb ("Tempo: diferença e repetição no Makrokosmos de George Crumb") sob a orientação do Prof. Dr. Luigi Antonio Irlandini, no Departamento de Música da Udesc Universidade do Estado de Santa Catariana, Brasil. Seus interesses de pesquisa incluem também os estudos sobre tempo, processos de criação musical, composição assistida por computador (OpenMusic), Live Electronics (MAX). Sua experiência em pesquisa inclui a participação e apresentação de seus artigos nos principais congressos brasileiros. 


\section{Introdução}

O processo, desde a concepção das ideias até o início da elaboração dos materiais, passa por diferentes meios que nem sempre são ponderáveis. Por materiais entende-se "as matérias inanimadas, com as quais se pode construir a obra: as alturas e as durações. Essas são quantificáveis e parametrizáveis, as notas propriamente ditas"2 (HERVÉ, 1999, p.44, tradução minha). A minha música instrumental sempre parte da escrita, a exemplo de outros compositores, dentre eles Philippe Manoury, o qual afirma que "o ato de compor também pressupõe uma representação mental da escrita. Então, se você me perguntar como uma ideia musical surge quando eu componho, responderei que muitas vezes ela está na forma de sua representação gráfica ${ }^{3 "}$ (MANOURY, 2017 p.38 tradução minha). Esta declaração do compositor Philippe Manoury resume, de certa forma, o gérmen do pensamento musical do ocidente. Dessa mesma maneira, a elaboração de Os pássaros no Delta do Jacuí, peça de minha autoria sobre a qual discorrerei neste artigo, surge através da escrita musical ${ }^{4}$.

Antes de prosseguir para os aspectos da composição propriamente dita, acredito ser pertinente dizer algo sobre a relação entre ideias e materiais, pois trata-se de um processo composicional peculiar para essa peça, decorrente da decodificação de uma imagética - o Delta do Jacuí - da escuta de um material sonoro pertinente a esse mundo e de uma ferramenta específica de orquestração assistida por computador, da qual me utilizei para extrair certas texturas. Em consequência disso, surgiram muitos questionamentos que serviram de balizamento para pensar os processos que seriam empregados. Questões essas, tanto de natureza criativa, como a relação do canto dos pássaros com outros sons, quanto de natureza técnica, como resolver uma maneira de integrar o canto dos pássaros no decurso temporal. Também foi necessário decidir se a parte eletroacústica que eu pretendia incluir seria ou não ad libtum. Optei por essa alternativa no sentido de deixar a decisão a critério do intérprete. Penso que o intérprete deve ter sempre uma participação ativa nas decisões que dizem respeito ao processo criativo da mediação entre a composição e sua recepção. Por fim, elaborei 27 arquivos independentes de áudio que devem entrar em pontos específicos marcados na partitura, que, a critério do músico responsável pela difusão eletroacústica, podem ser projetados espacialmente da maneira que este desejar.

O primeiro material de que me servi foi obtido de uma leitura espectral, algo ainda sem a dimensão temporal, apenas um único instante. Extraí diversas outras leituras instantâneas de uma amostra sonora de pouco menos de dois segundos; dentre essas análises, obtive uma determinada frequência, nota central. A seguir realoquei esta nota

\footnotetext{
2 Original: "La matière inanimée, avec laquelle on construit l'oeuvre: les hauteurs et les durées. C'est ce qui est quantifiable et paramétrable, les notes finalement" (HERVÉ, 1999, p.44).

3 Original: "L'acte de même de composer présuppose une représentation mentale d'écrit. Ainsi, si vous me demandez de quelle manière me vient une idée musicale lorsque je compose, je vous répondrai que c'est très souvent sous la former de sa représentation graphique" (MANOURY, 2017 p.38).

$4 \quad$ Salvo a parte eletroacústica.
} 
numa esteira temporal, de modo a criar uma reiteração capaz de estabelecer o sentido de permanência. Deste princípio decorre o desdobramento temporal do tempo, que se desfaz à medida que é criado, tal qual propõe Silvio Ferraz no que ele denomina "fórmula do tempo".

Transformação e esquecimento: a transição, mesmo que lenta, e o corte brusco dão então nascimento ao que chamarei aqui de tempo. Mesmo que o tempo já tenha sido fundado sobre o falso contínuo, aquele de microciclos contraídos, ou pela reiteração imediata, é somente quando a permanência se desfaz que me dou conta de que ele existe - o tempo nasce para mim quando perco o chão. A transformação contínua e o corte retiram, em velocidades diferentes, o chão; retiram a base, e tudo que estamos vivendo se torna quase que solto, sem contiguidade. (FERRAZ, 2005, p.95).

O microciclo do qual nos fala Silvio Ferraz é, do ponto de vista métrico, apenas a reiteração das subdivisões de uma determinada unidade de tempo, que, mesmo não estando necessariamente escrita, se faz presente como percepção do pulso. Este mesmo mecanismo de transformação contínua e corte já está presente em Stravisnky - $A$ Sagração da Primavera - no 13 "Les augures". Todavia, no caso da minha peça, este mecanismo opera de maneira distinta ao fazer com que na mesma razão em que a noção de permanência se desfaz faço nascer outros tempos através do jogo de estabilidade e instabilidade, no qual o contínuo é apenas a reiteração da primeira nota - que logo deixará de ser percebido. Ao longo de toda a peça, cujo processo descrevo neste artigo, o tempo é completamente mensurado. Isto é, sempre existe um pulso, mas trata-se de uma referência que transita em mais de uma camada, assim como em Stravisnky.

Na primeira camada, uma única nota é reiterada e estabelece um senso de continuidade; um nível acima desta primeira camada é caracterizado pelo agrupar das figuras curtas dentro de um pulso maior, que cria a expectativa da permanência do tempo extenso ${ }^{5}$, expectativa essa que é contrariada a cada deslocamento de acentuação.

No transcorrer da música, o ouvinte passa a perceber que, em meio ao fenômeno da não permanência métrica, certos elementos são recorrentes ou periódicos. Adiante, percebe o surgimento de uma nova unidade de pulso, que, por irregular que seja, é percebida como agrupamento de um pulso menor - um nível abaixo. Todo esse jogo de tempo e pulso que constitui a estrutura rítmica é construído num plano e desvanece em outro. Nesse sentido, o tempo é mais do que a percepção do objeto, ele tornou-se a diferença. Trata-se de um tempo até certo ponto direcionado, ainda que não totalmente linear, pois a linearidade do tempo implica a sucessão de eventos únicos, irreversíveis e direcionados ao futuro (próximo instante). Tal irreversibilidade existe no sentido de que os eventos não podem ser retomados.

50 que chamo aqui de extensivo é, em referência a Bergson, a apreensão sensorial que nos permite perceber distinguir o objeto "tempo" do instante. 
O tempo linear, que, em analogia às ciências físicas, chamarei de temps fléché, é um tempo musical irreversível, em que cada instante é definido de acordo com instantes anteriores, em que o ouvinte percebe uma progressão do passado para o futuro: noções de previsibilidade e expectativa são ingredientes essenciais no temps fleché7. (BAILLET, 2001, p.158-159, tradução minha).

Já na peça em questão, os elementos são tratados de maneira a pensá-los como que "fora do tempo", de tal sorte que possam ser repetidos - tal qual um fotograma recorrente que surge de diversas maneiras, sem relação com os demais. Considero ainda que a noção de tempo da qual me utilizo nessa composição não é linear porque o meu raciocínio, no caso, não privilegia previsibilidade e expectativa. Trata-se do mesmo princípio já definido por Ivanka Stoïanova como "motivação bivalente", que foi retomado por Silvio Ferraz e que tem por resultado um processo ilimitado de encadeamentos (FERRAZ, 1998). Estou falando aqui de um tipo organização de elementos maiores, aqueles percebidos em blocos. São pássaros transcritos, fragmentos de sonoridades que são permutados. Esta permutação é feita indo e voltando no eixo linear do tempo, de tal modo que a decorrência passada de um bloco não implica sua reiteração em outro momento, tal é a natureza da permutação em que $A B=B A$. Cada bloco possui uma direcionalidade independente do seu antecedente, que resulta numa pluridirecionalidade dos elementos, como esclarece Ferraz (1998, p.110).

Esta pluridirecionalidade, que excluindo-se o grau de complexidade que o enunciado possa vir a ter, é resultado de direcionalidades individuais. O que se supõe aqui é que o discurso deixe de ser dependente do resgate futuro da representação dos eventos. A coexistência de eventos que, ora recapitulam o passado, ora determinam o futuro, teria por resultado uma escuta bifocada: os eventos apontariam para sentidos opostos na linha do tempo.

Não obstante, muitos elementos na escrita composicional possuem alguma direcionalidade temporal, mas mesmo esses são retirados do eixo temporal quando submetidos a operações de permutação e aumentação de unidades de pulso, o que leva a dizer que tempo totalmente direcional, nesta peça, só existe na composição da parte eletroacústica. Nessa é criada uma ressonância na esteira temporal que não pode ser permutada. Cada um dos 27 trechos só existe para, e em função, do momento a que se destina. Na performance pode-se suprimir esta ressonância, mas não mudar a ordem estabelecida, visto que ela foi concebida em função de um tempo não reversível.

\section{Processo de composição em Os pássaros no Delta do Jacuí}

É sempre difícil falar da própria obra sem parecer pretensioso ou demasiadamente subjetivo, como que querendo justificar as opções composicionais por motivos alheios

\footnotetext{
6 Optei por manter este termo na tradução devido à falta de uma tradução precisa, muito embora tempo direcional seja também uma opção viável.

$7 \quad$ Original: "Le temps linéaire, qu'en analogie avec les sciences physiques j'appellerai temps fléché, est un temps musical irréversible, où chaque instant se définit en fonction d'instants antérieurs, où l'auditeur perçoit un déroulement de passé ver le futur: les notions de prévisibilité et d'attente sont des ingrédients indispensables au temps fléchés" (BAILLET, 2001, p.158-159).
} 
à música. Por outro lado, penso também ser difícil escrever música procurando referendar cada decisão tomada durante a composição, como se o autor estivesse analisando a obra antes mesmo que ela tenha sido escrita ou, ainda, como se inventasse uma teoria antes da composição. Acredito que todas as referidas possibilidades existem e, sem juízo de valor, há quem as prefira. No meu caso, optei por trabalhar em camadas, num processo que a teoria decorre da prática, ao mesmo tempo em que a teoria de outros autores se torna prática.

Esta é a primeira de duas peças que compõem O Delta do Jacuí, que por sua vez é a primeira parte da trilogia Águas do Rio Grande. Essa obra, mesmo que diretamente relacionada, não é uma leitura objetiva da hidrografia do Rio Grande do Sul, mas apenas uma sugestão de imagens e memórias sobre alguns de seus aspectos. A ideia dessa composição surgiu a partir de diversas viagens que fiz a Porto Alegre e de incursões ao Vale dos Sinos, quando tive a oportunidade de conhecer, ainda que a distância, o Delta do Jacuí. A trilogia das Águas do Rio Grande decorre dessas imagens do Delta e do lago Guaíba; sendo a terceira parte um tanto mais abstrata, pois contém apenas a ideia da água em direção ao mar. A região do Delta do rio Jacuí é uma área de proteção ambiental localizada na região metropolitana de Porto Alegre, que, assim como muitos outros biomas próximos a regiões densamente povoadas, sofre com a poluição. Ainda assim, resiste ao manter suas características e apresentar vários tipos de aves típicas das regiões de banhado e espécies migratórias, dentre outras mais comuns, que são facilmente encontradas nos centros urbanos, mas que também vêm transitar pelo mesmo ecossistema, perfazendo assim uma fauna aviária muito diversificada.

Nesta peça, Os pássaros do Delta, há um colóquio entre cinco espécies passeriformes: bem-te-vi (pitangus sulphuratus); trinca-ferro (saltator similis); sabiá-coleira (turdus albicollis); uma espécie da ordem craciforme, o jacu (penelope); e uma da ordem caradriiforme, o quero-quero (vanellus chilensis). O canto dessas aves foi transcrito através de observação e escrita, sendo cada um deles apresentado individualmente e depois reelaborado. Também foi realizada a análise espectral das amostras dos cantos através de ferramentas como Spear e a biblioteca Super-VP do OpenMusic - processos que serão abordados mais detidamente adiante -, que resultaram em dados os quais foram transcritos para a partitura. Dentre as referidas ferramentas, destaco o uso do Orchids, que é um programa de orquestração assistida por computador desenvolvido no Ircam pelo compositor e pesquisador Yan Maresz. Com o auxílio deste programa, as amostras de sons gravados das três espécies de pássaros citados nesta obra foram orquestradas para a instrumentação disponível.

A escolha da instrumentação, embora parcialmente limitada pela ocasião ${ }^{8}$, norteou-se pelo raciocínio de incluir a maior diversidade de famílias de instrumentos. Este critério deve-se ao fato de que as experimentações preliminares com o programa Orchids revelaram que este produz resultados mais efetivos - através do uso de centroide espectral - quando a instrumentação é variada. Dentre os instrumentos disponíveis, a 
instrumentação foi delimitada em: oboé, clarinete, violino, cello, contrabaixo, xilofone e percussão (bongô, conga, agogô e, tam-tam).

A ideia principal da composição é intercalar as transcrições "livres" junto às orquestrações propostas pelo Orchids, através das quais ocorre uma análise espectral em tempo dilatado, formando assim um mosaico por sobreposição e justaposição de elementos. Este tipo de construção já se encontra em Messiaen.

A forte justaposição de ideias nos trabalhos iniciais tornou-se eventualmente sofisticada, envolvendo tanto a superposição quanto a justaposição. O resultado final é uma refinada estrutura de colagem, tal como a usada em Couleurs de la cité celeste, na qual não somente a melodia, mas também o ritmo e o timbre interagem para formar a colagem total ${ }^{9}$. (JOHNSON, 1989, p.24, tradução minha).

Tendo em vista esses fatos, e de pronto assumindo um diálogo direto com as técnicas composicionais de Messiaen, considero pertinente chamar atenção para o fato de que, mesmo que esta peça não pretenda se comparar em nenhum aspecto a qualquer composição de Olivier Messiaen - e muito menos se proponha a ser algum tipo prosseguimento -, resvala no risco de cotejá-lo em certas peculiaridades, tendo em vista o uso de técnicas criadas e consagradas por Messiaen. Entretanto, cabe dizer que o uso de temáticas e técnicas criadas ou consagradas por outros compositores não constitui necessariamente uma alusão. Pássaros, por exemplo, têm sido trazidos para a música por inúmeros compositores ao longo de toda a história da música ocidental. Para permanecer apenas no compositores nascidos no século XX, tal qual Messiaen, destaco alguns compositores de escolas e localidades variadas: Toru Takemitsu (1930-1996), Einojuhai Rautaavara (1928-2016), José Antonio de Almeida Prado (1943-2010), François-Bernard Mâche (1935), Luigi Irlandini (1959), dentre outros, tendo cada um deles abordado essa questão ao seu modo.

Além do canto dos pássaros, o tempo é outro elemento significativo na peça. Logo no início é apresentado um pulso contínuo. Sua função é estabelecer uma unidade de tempo com acentuação irregular, de tal modo a deixar clara a relação de cronoametria ${ }^{10}$ dentro de uma unidade básica de pulsação. A percepção do tempo, através da qual procurei balizar esta periodicidade métrica em relação a um pulso mínimo, pode ser grafada de diversas maneiras, que, como afirma Souvtchinsky, atua como uma notação secundária.

A natureza da música cronoamétrica é sempre psicológica: é somente através de seus reflexos psicológicos que pode ser expressa. Esta música é, por assim dizer, uma notação secundária de impulsos emocionais primários, das declarações e projetos do autor. Nesta música, os centros de gravidade estão deslocados ${ }^{11}$. (SOUVTCHINSKY, 1939, p.72, tradução minha).

$9 \quad$ Original: "The stark juxtaposition of ideas in earlier works eventually becomes sophisticated in the 40' with superimposition as well as juxtaposition being involved. The eventual outcome is a refined collage structure such as is used in Couleurs de la cité celeste, where not only melody and harmony but also rhythm and timbre interact to form the total collage" (JOHNSON, 1989, p.24)

10 Inicialmente, a cronoametria se estabelece apenas pela acentuação.

11 Original: "La nature de la musique Chrono-amétrique est toujours psychologique; ce n'est que par elle que peuvent être exprimés les réflexes psychologiques. Cette musique est, pour ainsi dire, une notation secondaire de impulsions émotives primaires, des états et des projets de I'auteur. Dans cette musique, les centres d'attraction et de gravité sont, en sommes, déplacés" (SOUVTCHINSKY, 1939, p.72). 


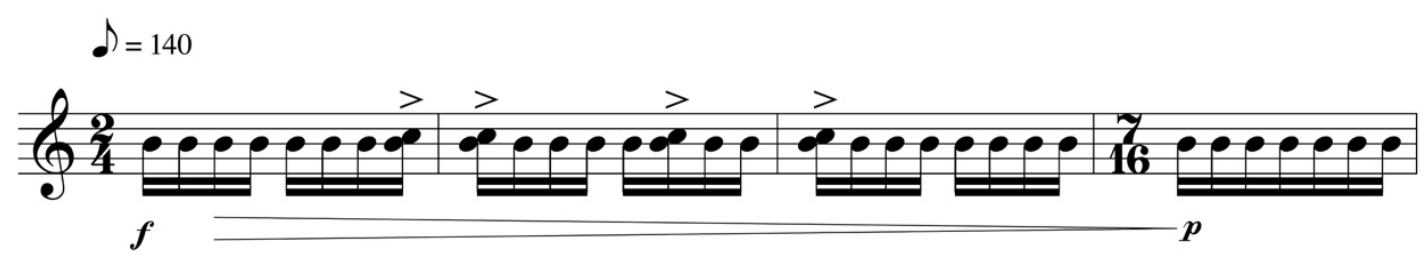

Fig. 1: Pulso e cronoametria

O mesmo ocorre em relação à notação do canto dos pássaros, para a qual somos levados a estabelecer alguma unidade de pulsação e desta abstrair proporções - que não necessariamente se mantêm constantes. No caso específico d'Os Pássaros do Delta, estabeleci a semicolcheia como unidade mínima através da qual a métrica da peça toda foi construída. Antes de seguir adiante, para justificar a inserção de um longo trecho em fusas, algo deve ser dito acerca da relação entre a escrita do compositor com a leitura do intérprete. Durante os ensaios, os músicos foram chamados a participar na adequação e refinamento da escrita musical. Inicialmente, nos trechos em que havia mudanças de unidade de pulsação, foram sugeridas outras opções. O ponto mais conflitante foi um trecho em que havia uma mudança de andamento no sentido de manter a semicolcheia como a menor figura regular. Isso causou muita confusão entre o regente e os músicos. Para resolver este trecho específico, foi sugerido que se escrevesse toda a passagem em sequência de fusas, em vez de dobrar o valor do andamento para manter as semicolcheias. Nesse caso, em função de maior clareza e facilidade para os intérpretes, sacrifiquei a escrita em torno de uma única figura de duração mínima. Em decorrência disso, foi possível certa flexibilidade na transcrição do canto do bem-te-vi.

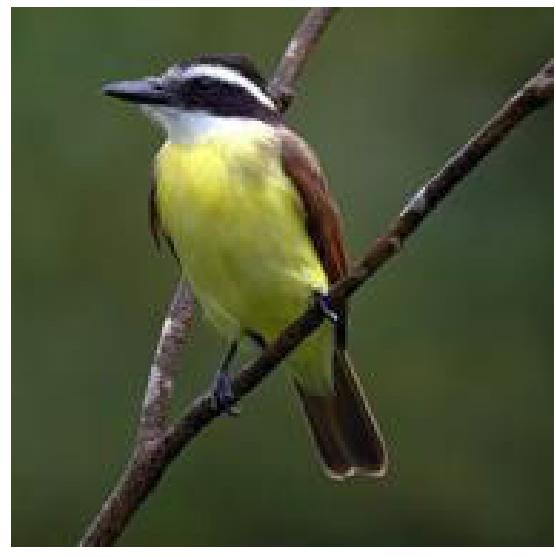

Fig. 2: Bem-te-vi

O pitangus sulphuratus (SICK, 2001), o bem-te-vi - ilustrado na Fig. 2 -, é uma ave passeriforme da família dos tiranídeos, facilmente reconhecida por seu canto onomatopeico que varia de acordo com o idioma local. Em países de língua inglesa, é chamado de kiskadee, que em nossa língua equivale ao mimologismo "bem te vi". Muito embora esta figura onomatopeica seja o padrão reconhecido do canto desta ave, a observação da vocalização desta espécie de pássaro revela uma grande variedade de ritmos. Após transcrever esses padrões, realizei operações de adição e permutação, como no exemplo da Fig. 3. 


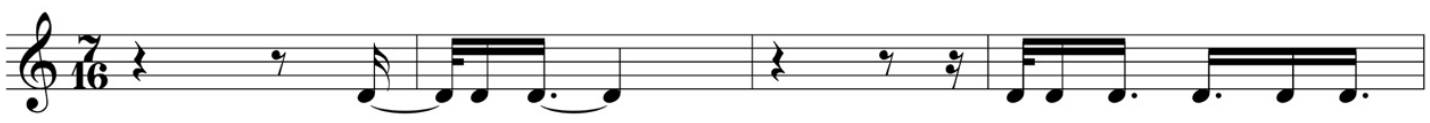

Fig. 3: Motivo do bem-te-vi executado pelo tam-tam

Essa associação rítmica, por onomatopeias, possibilitou-me uma outra maneira que, embora simples, é, ao mesmo tempo, muito potente em termos de abstração: a ideia dos pés gregos, que novamente se reporta às práticas de Messiaen. $O$ tipo de desdobramento que empreguei ao "reelaborar" o canto do bem-te-vi procede por combinações e permutações de pés gregos, algo que ocorreu naturalmente, muito embora as primeiras elaborações deste motivo rítmico tenham sido baseadas no ritmo de três valores - não retrogradável - e no Ragavardhana.

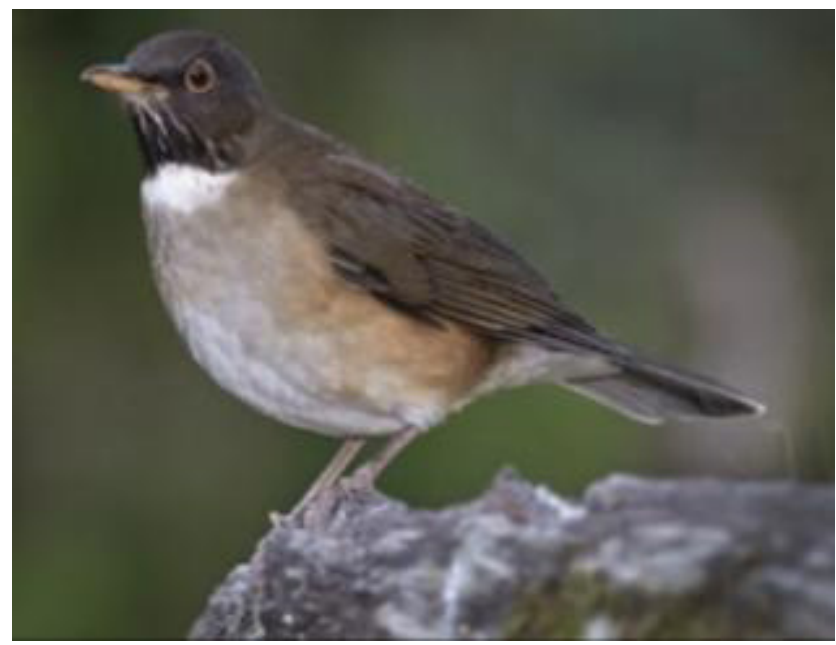

Fig. 4: Sabiá-coleira

O próximo pássaro que surge é o sabiá-coleira, Turdus albicolis (SICK, 2001), ilustrado na Fig. 4. Esta espécie, a exemplo do bem-te-vi, é uma ave muito difundida em todo o Brasil, tanto nas regiões de mata quanto nas áreas urbanas. Vale a pena destacar que as amostras de canto do sabiá-coleira que utilizei para a análise e transcrição foram gravadas na região metropolitana de São Paulo, incluindo diversas gravações feitas no campus da Cidade Universitária de São Paulo.

A transcrição do canto do sabiá-coleira se deu de maneira bem mais empírica e, por assim dizer, escolástica. Após selecionar uma amostra e delimitar um trecho, ouvi inúmeras vezes, procurando a grafia mais aproximada até chegar à versão que me pareceu satisfatória, tal como está na Fig. 5.

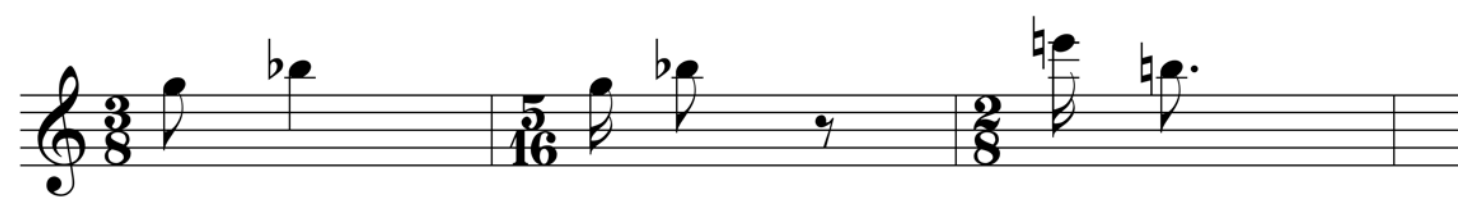

Fig. 5: Transcrição do tema do sabiá-coleira 
Ao contrário do canto do bem-te-vi, no qual não procurei trazer qualquer aspecto melódico, o canto do sabiá-coleira apresenta um contorno melódico bem definido; porém, como Messiaen já afirmara anteriormente, é inútil tentar reproduzir o canto dos pássaros, de tal forma que, ao invés de qualquer preocupação com exatidão de alturas, o meu objetivo foi criar uma sonoridade própria, desde que permanecesse circunscrita aos limites do perfil melódico. Além do mais, "pelo que já foi visto, o canto dos pássaros é suscetível a uma análise basicamente textural, no nível de seu contorno melódico, dada a não pertinência do sistema de alturas na alteração das figuras melódicas" (FERRAZ, 1987, p.23). Por isso, não se deve esquecer de que há o elemento timbrístico, muitas vezes desconsiderado, principalmente pelos ornitólogos, mas que no contexto musical é de extrema importância, e que Messiaen destaca com propriedade.

São necessárias combinações instrumentais muito complicadas apenas para evitar que a melodia de um pássaro seja uma caricatura. Para melodia e ritmos, sempre tentei gravá-los com a maior precisão, com a única diferença de que os outros não são executáveis. Mas eu sempre respeito a escala de valores diferentes; as relações entre os sons e as durações permanecem as mesmas, com uma ligeira mudança de tempo e registro, o que, repito, não destrói as relações ${ }^{12}$. (MESSIAEN apud TREMBLAY, p.18, tradução minha).

Valendo-me do mesmo sentido heurístico que empreendi para a transcrição rítmico-melódica, elaborei a orquestração que é exemplificada na Fig. 6.

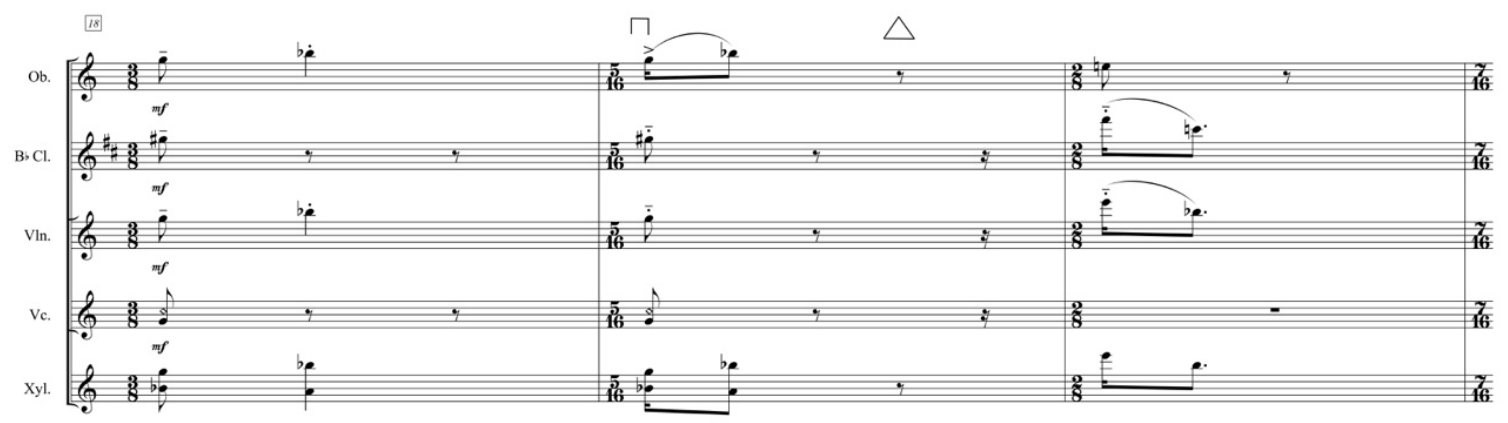

Fig. 6: Os pássaros do Delta, compassos 18-20 (orquestração do sabiá-coleira)

No trecho da Fig. 6, a melodia inferida pelo canto do sabiá aparece no xilofone e é acrescida por notas que formam intervalos de sexta maior e nona menor. Com exceção do contrabaixo e da percussão, que participam mais como elemento rítmico, os demais instrumentos reforçam os ataques ora dobrando em oitava a nota mais aguda do xilofone, ora em intervalos de sétima ou nona ${ }^{13}$.

Este tipo de construção é decorrente da busca de uma sonoridade que permeia a escuta dos pássaros, e, tal qual se pode constatar na análise da primeira das Petites es-

\footnotetext{
12 Original: "Il faut des combinaisons instrumentales très compliquées pour arriver seulement à ne pas caricaturer un timbre d'oiseau. Pour la mélodie et les rythmes, j'ai toujours essayé de les noter avec la plus grande précision, avec cette seule différence que les autres n'étant pas exécutables. Mais je respecte toujours l'échelle des différentes valeurs; les rapports entre les sons et les durées restent les mêmes, avec un léger changement de tempo et de registre, qui, je le répète, ne détruit pas les rapports" (MESSIAEN apud TREMBLAY, p.18). 
quisses d'oiseaux, Le Rouge Gorge, "Os intervalos de nona e sétima são predominantes, sendo algumas vezes acrescidos de segundas, quartas e quintas, e isso resulta em uma conformidade tímbrica" (MOREIRA, 2008, p.190). Tal conformidade tímbrica, evocada por esses intervalos, é recorrente em muitas passagens de Messiaen - mesmo aquelas que não necessariamente estão ligadas a pássaros -, como também se observa no caso da música para órgão. A esse respeito, é preciso considerar que a registração desse instrumento desempenha um papel fundamental na identidade timbrística e que antes já está presente no raciocínio de Debussy, como menciona Diether de la Motte (2009) em seu Harmonielehre. Em Messiaen, a relação entre harmonia e registração do órgão é uma via de duas mãos, no sentido de que tanto a registração propõe uma harmonia quanto a própria harmonia acaba por influenciar a criação de novos registros, o que se confirma pelo fato de que Messiaen solicitou que se adicionassem novos registros ao tradicional órgão Cavaillé-Coll ${ }^{14}$ da igreja La Trinité, em Paris, onde ele foi organista desde 1931 até a sua morte.

Messiaen expandiu o seu potencial sonoro ao adicionar mais misturas e mutações. Assim, o instrumento foi capaz não somente de tocar grandes tutti e registrações em bloco, mas também combinações coloridas, tais como no Positivo Quintaton 16' e Nazard 2 2/3' ou no Grande Órgão Clairon 4' e Plain jeu IV ${ }^{15}$. (BENITEZ, 2008, p.143, tradução minha).

Isso aponta para o fato de como a construção do timbre em Messiaen está, em grande parte, ligada ao som do órgão. Na Fig. 7 está um exemplo de uma registração feita por Messiaen.

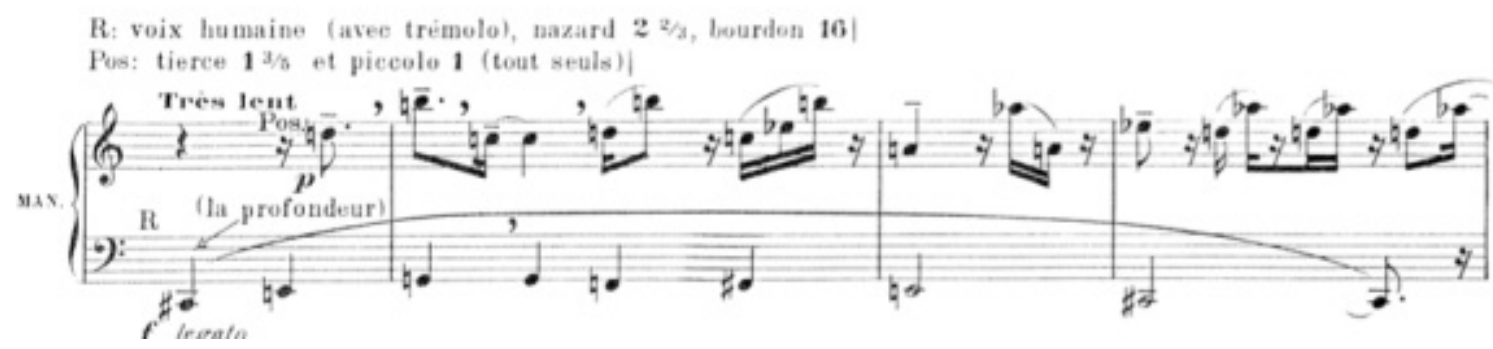

Fig. 7: Compassos 14-17 da peça Les mains de l'abime do Livre d'Orgue

A mutação é um registro formado por um conjunto de tubos que produz um som não correspondente à oitava em relação à nota tocada. O nazard $22 / 3$, por exemplo, soa uma oitava e uma quinta acima da nota real acionada nos manuais ${ }^{16}$. No caso do exemplo da Fig. 7, Messiaen indica para o positivo: tierce $13 / 5$ e piccolo 1 . O resultado

\footnotetext{
14 Aristide Cavaillé-Coll (1811-1899) foi o mais importante construtor de órgãos na França. São de sua autoria os órgãos instalados nas igrejas Madelaine e Trinité, onde Messiaen foi organista. Na cidade de São Paulo existem dois Cavaillé-Coll: um na Igreja São José do Ipiranga e outro na Igreja Senhor do Bom Jesus do Brás.

15 Original: "Messiaen expanded its sonorous potential by adding more mixtures and mutations. Thus the instrument was capable not only of grand tuttis and block registrations but also colorful combinations, such as the Positif's Quintaton 16' and Nazard 2 2/3', or the Grand Orgue's Clairon 4' and Plein Jeu IV"' (BENITEZ, 2008, p.143).

16 Cada teclado do órgão é chamado de manual, sendo variáveis suas disposições no console, conforme a tradição do país e do construtor. Os três principais tipos de manual são: recitativo, positivo e grande órgão.
} 
dessa combinação é um som duas oitavas e uma terça acima da nota escrita. Para o manual récitativ, a registração anotada na partitura pede uma combinação de Voix humaine (com tremolo), nazard 2 2/3 e bourdon 16 . Ao observarmos essa combinação, podemos concluir que uma simples tríade maior, mesmo que distribuída de maneira bastante ortodoxa, produz parciais que pertencem a um acorde com sétima maior e nona (Fig. 8).

Aparentemente isto tudo já está contido na série harmônica, não fosse pelo fato de que na série harmônica existe um intervalo de sétima menor ${ }^{17}$. No caso do exemplo da Fig. 8, a sétima não somente é maior, mas também é decorrente de um intervalo de terça maior em relação à nota Sol; ou seja, é rigorosamente alta; o mesmo ocorre em relação à nota Ré, que surge como quinta justa de Sol.

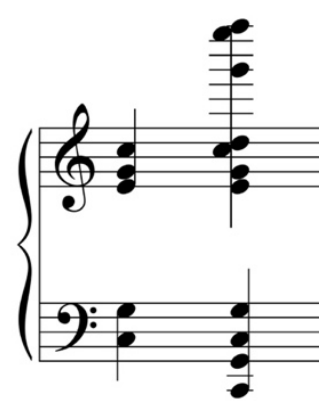

Fig. 8: Parciais resultantes da registração indicada por Messiaen

Deve-se lembrar, no entanto, que Messiaen afirmava ser capaz de perceber toda a gama do espectro sonoro e, dessa forma, ele estava ciente das diferenças entre as parciais de cada som da série harmônica e daquelas resultantes da registração obtida ao órgão (sendo que mesmo nesse instrumento existe uma série de parciais para cada registro, especialmente para aqueles que utilizam tubos com linguetas - como no caso do nazard, por exemplo).

Se você tocar uma nota com muita suavidade no piano e esperar por um momento, ouvirá a oitava, a quinta, a terça, a sétima, e eu, que tenho um ouvido treinado, ouço a nona, a quarta aumentada etc. Ouço toda a série de harmônicos . (MESSIAEN, 1979, p.5, tradução minha) ${ }^{18}$.

Fica evidente, portanto, que Messiaen considerava toda essa resultante sonora (ainda que fosse apenas como recurso colorístico) como material composicional, e por esse mesmo motivo a apropriação deste tipo de procedimento, em outros contextos composicionais, é capaz de gerar diversos materiais.

Outro caso a se considerar nessa mesma obra, Livre d'Orgue, reporta-se à temática de pássaros, como ilustrado na Fig. 9. Ali encontramos uma escrita vertical e o uso do registro Cymbal, o qual Messiaen pediu que fosse alterado quando o Cavaillé-Coll da Saint-Trinité foi restaurado em 1965. Consta que ele desejava reduzir o efeito percussi-

\footnotetext{
17 Na realidade, é menos que uma sétima menor.

18 Original: If you play a very low note on the piano and wait for a moment, you'll hear the octave, the fifth, the third, the seventh, and since I have a highly trained ear, I hear the ninth, the augmented fourth, etc. I hear a whole series of harmonics. (MESSIAEN, 1979, p.5)
} 
vo deste registro (GLANDAZ, 1988), o que sugere que esta característica possivelmente atrapalhava a definição dos sons produzidos e, consequentemente, a acuidade dos intervalos que ele desejava ouvir - o que é de fato esperado, uma vez que o nome do registro, cymbal, sugere que fora projetado efetivamente para fornecer um resultado percussivo e de sons inarmônicos.

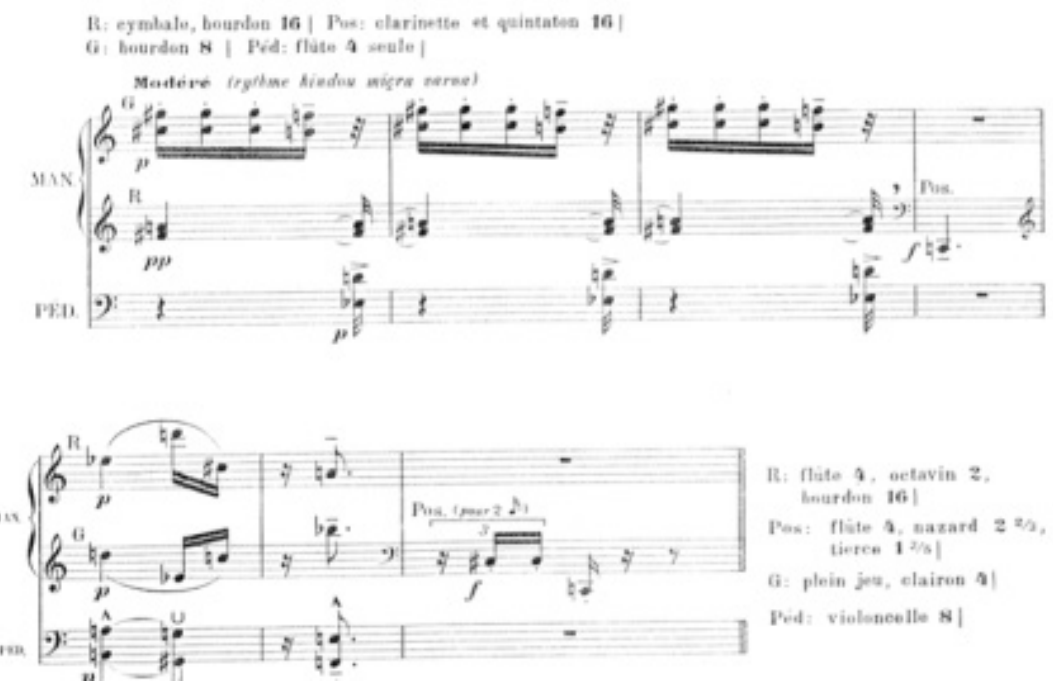

Fig. 9: Primeiros sete compassos de Chant des Oiseaux do Livre d'Orgue

Apesar de os exemplos de peças para órgão que contêm materiais diretamente relacionados aos pássaros não serem tão abundantes quanto para piano ${ }^{19}$, estas já apresentam uma importante contribuição em termos de construção de timbre. Por meio das registrações, como se verificou, Messiaen deixa indícios claros de sua construção espectral. Ademais, no volume VII do Traité de rythme, de couleur, et d'ornithologie, ele afirma como as cores mudam em razão de quão grave ou agudo os acordes estejam situados.

As cores de um mesmo acorde mudam 12 vezes a cada semitom - elas são mais brilhantes nas oitavas agudas e mais escuras nas oitavas mais graves -, mas podem ser modificadas ainda mais. Os outros fatores de mudança são: a duração e a brevidade dos sons, as diferentes intensidades (do pianíssimo ao fortíssimo), os ataques (legato, staccato, piqué sec, louré, arraché etc.) e especialmente os timbres e as combinações desses. Tudo isso influencia a cor musical e a torna permanentemente em movimento ${ }^{20}$. (MESSIAEN 1949, p.104, tradução minha).

Essa percepção, longe de ser subjetiva, pode ser desenvolvida durante toda a vida musical -seja do compositor, seja do intérprete - e é particularmente útil para aqueles que se dedicam às atividades ligadas à orquestração.

\footnotetext{
19 Não é necessário sequer fazer uma comparação em termos de números, visto que o Catalogue des Oiseaux supera qualquer quantidade de peças para outros instrumentos.

20 Original: "Les couleurs d'un même accord changent 12 fois a chaque demi-ton - elles se reproduisent en plus clair aux octaves aigues, en plus sombre aux octaves plus graves - mais elles peuvent subir encore d'autres modifications. Les autres facteurs de changement sont: la longueur et la brièveté des sons, les différentes intensités (du pianissimo au fortissimo), les attaques (legato, staccato, piqué sec, louré, arraché etc.), et surtout les timbres et les combinaisons de timbres. Tout cela influe sur la couleur musicale et la rend perpétuellement mouvante" (MESSIAEN, 1949, p.104)
} 


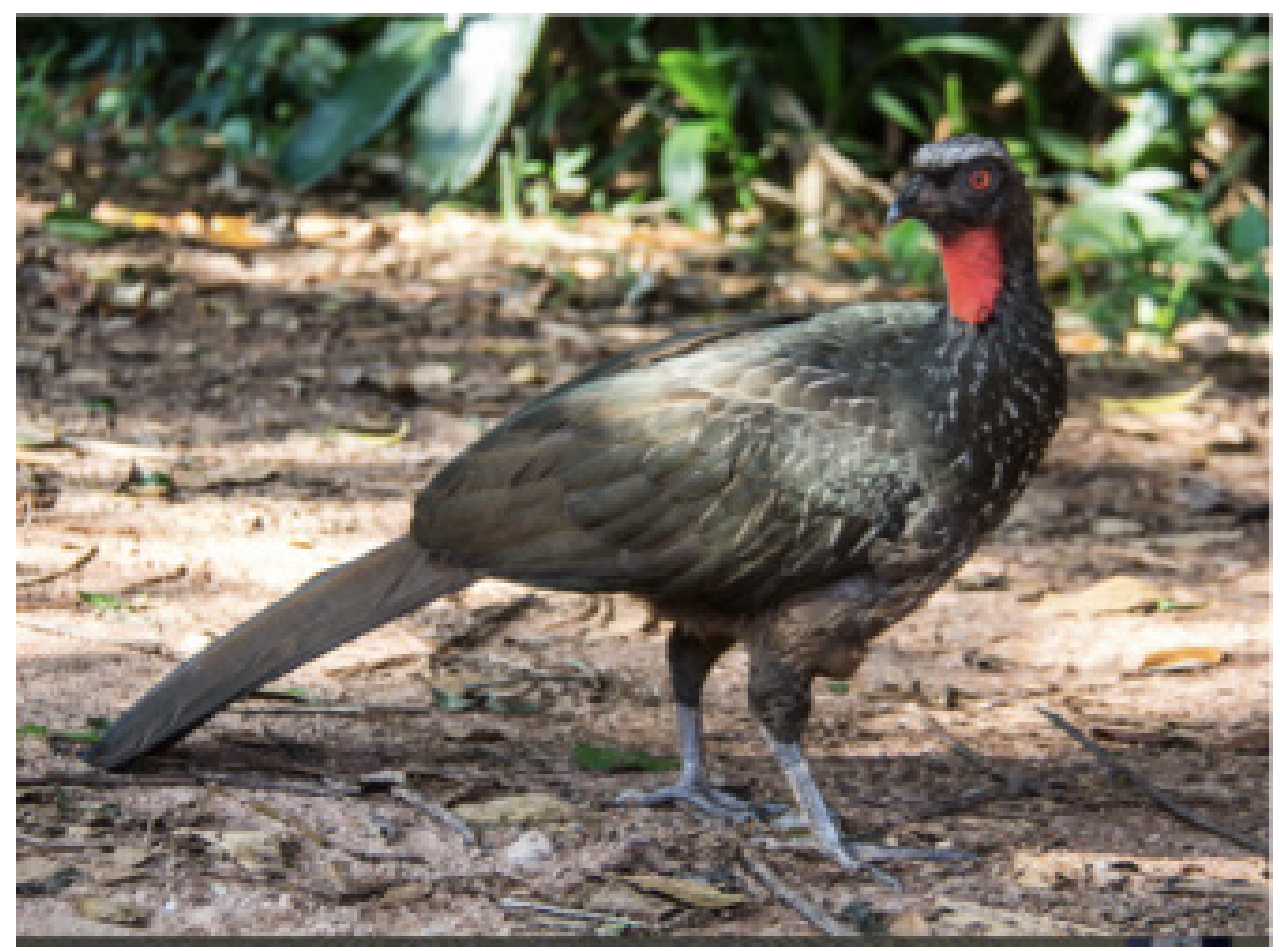

Fig. 10: Jacu

Até o momento, as transcrições utilizadas na composição da peça aqui em questão foram realizadas sem intervenção de qualquer aparato que não o gravador, tanto as rítmico-melódicas quanto as de caráter timbrístico. Para as duas próximas espécies, já foi utilizado o gravador para coletar amostras sonoras a serem analisadas. Trata-se de aves que, quando comparadas ao sabiá, possuem uma vocalização um tanto mais elementar do ponto de vista melódico, mas que, por outro lado, comportam uma grande variedade de artefatos. São elas: o jacu, Penelope jacucaca (SICK, 2001), e o quero-quero, Vanellus chilensis (SICK, 2001), nas Fig. 10 e 11, respectivamente.

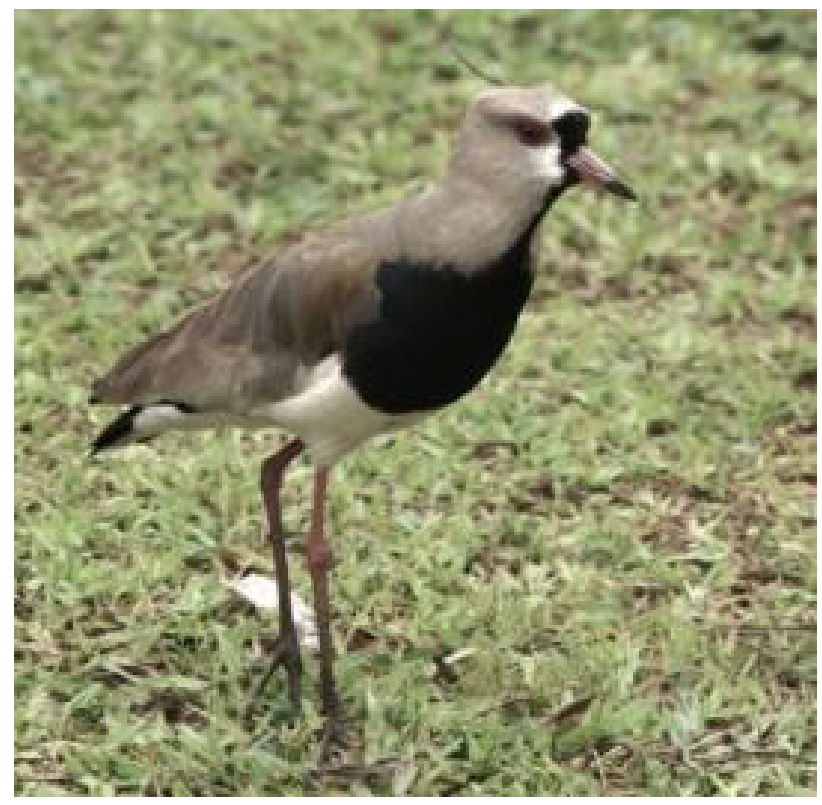

Fig. 11: Quero-quero 
Ao trabalhar com o canto do jacu ${ }^{21}$, uma ave cujo canto é bem mais rico em termos de parciais dentro da faixa audível de frequência, optei pelo uso do Orchids. Este programa possibilita gerar centenas de possíveis orquestrações através da escolha de parâmetros espectrais, e, ao contrário do seu antecessor - o Orchidée -, considera a evolução do som no tempo. Na Fig. 12, que corresponde aos compassos 48-53, está o resultado de uma das orquestrações fornecidas pelo Orchids. Esta foi a escolhida dentro de 150 propostas. Deve-se notar, entretanto, que, apesar de ser mais de uma centena de possibilidades, muitas delas são extremamente semelhantes. Optei por aquelas mais próximas da centroide espectral, e, dentre essas, as que melhor se adaptassem ao idiomatismo dos instrumentos, haja vista que algumas soluções faziam uso de muitas técnicas estendidas, e ainda outras usavam limites extremos dos instrumentos - os quais também foram usados, mas após considerar criteriosamente a sua exequibilidade ${ }^{22}$.

Tanto na orquestração assistida por computador quanto no tipo de transcrição empírica, considero inútil a busca por reproduzir o canto dos pássaros ou qualquer outro fenômeno. O uso do Orchids, como ferramenta de orquestração, é mais bem utilizado no sentido de empreender uma orquestração paramétrica, em detrimento do pensamento funcional. Evidentemente, o ser humano também é capaz de realizar uma orquestração paramétrica, muito embora até o século XX a orquestração tenha sido pensada de maneira eminentemente funcional. Já o Orchids, por outro lado, que opera exclusivamente por parâmetros - e não sofre a influência do hábito de "ouvir" as orquestrações do século XIX -, apresenta resultados interessantes e, na maior parte das vezes, improváveis ao nosso hábito de escrita, como se pode observar na Fig. 12.

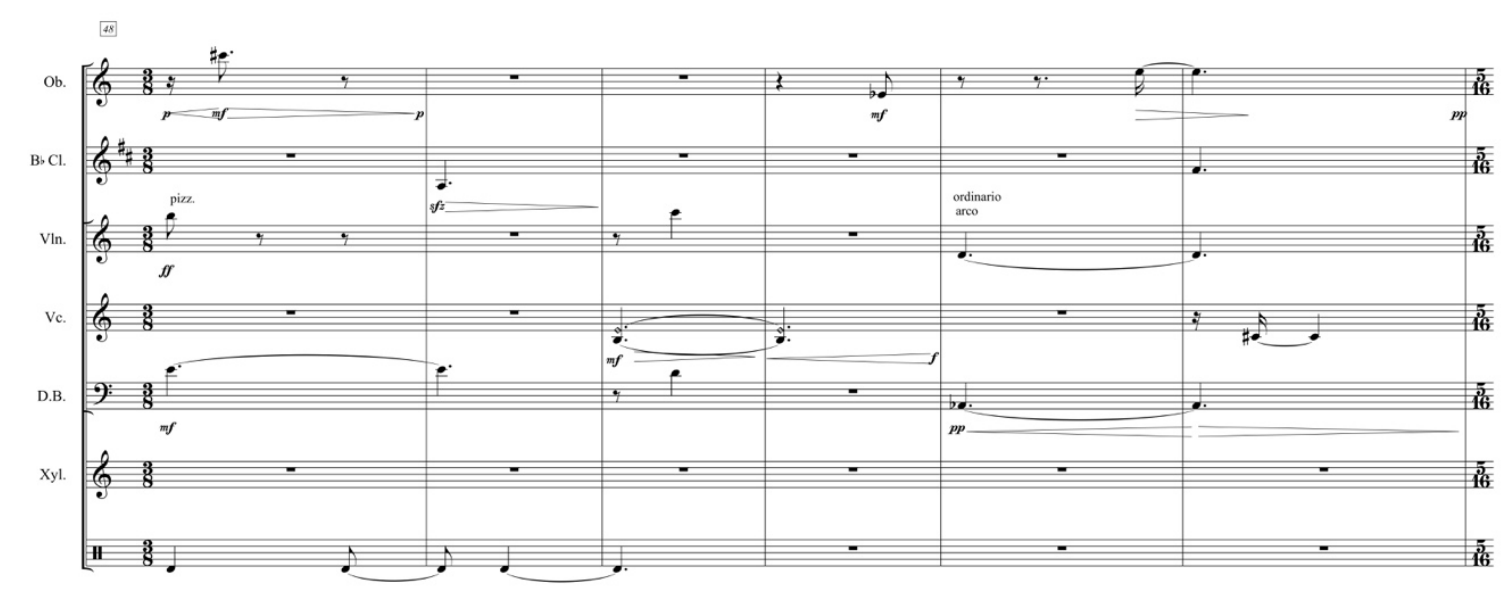

Fig. 12: Orquestração realizada no Orchids do canto do jacu

O último pássaro a ser apresentado é uma espécie menos frequente nas grandes áreas urbanas e, ao mesmo tempo, muito característica da região do Delta do Jacuí, cujo canto registrei quando estava na cidade de Porto Alegre: o trinca-ferro, Saltator similis (SICK, 2001).

\footnotetext{
21 Esta é a única ave cujo canto não foi selecionado diretamente por observação. A fonte sonora deste canto é proveniente das gravações do prof. Jacques Vieillard (1944-2010).

22 Como no caso de uma nota extremamente aguda para o oboé, como oboísta, julguei pertinente o uso, principalmente tendo em vista que o intérprete para o qual eu escrevia, Alexandre Ficarelli, é um músico extremamente habilidoso.
} 


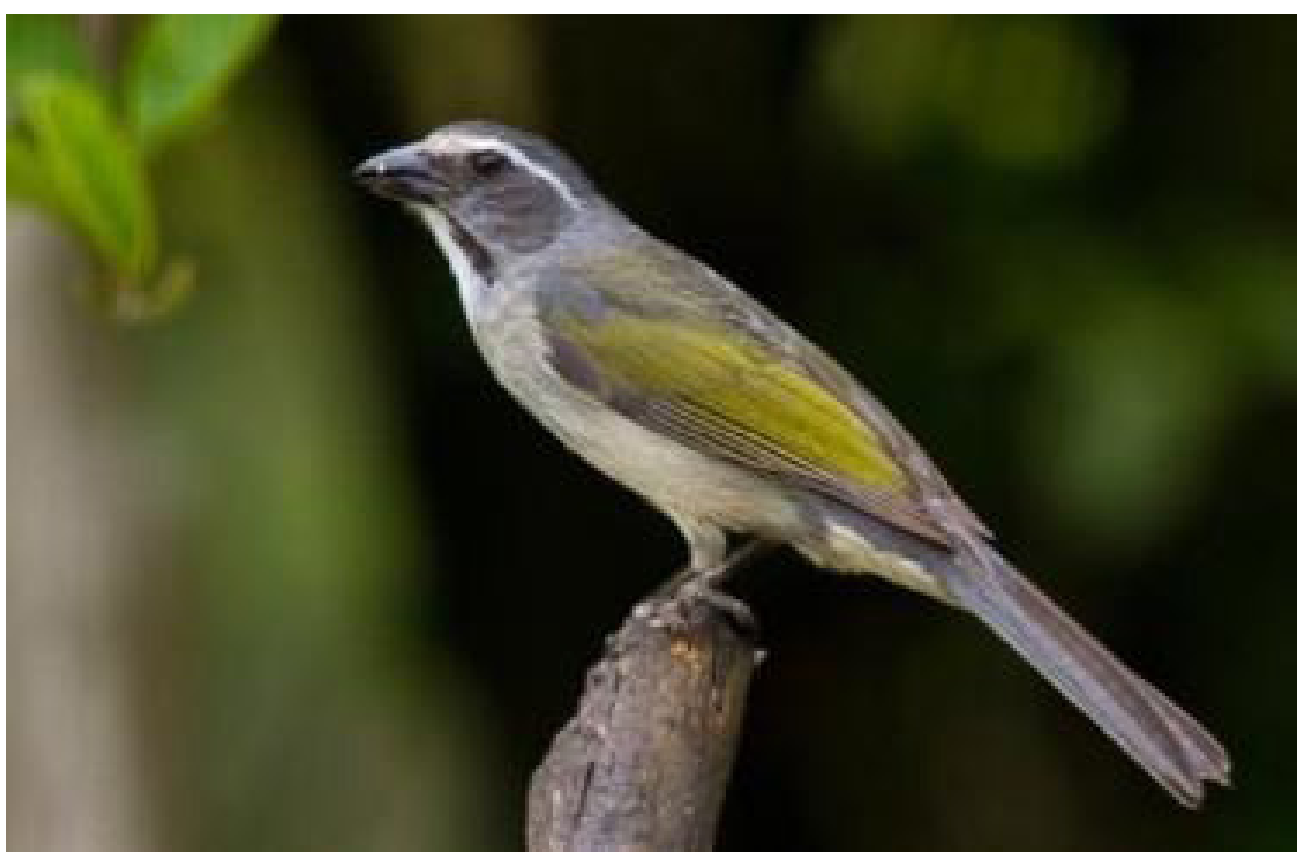

Fig. 13: Trinca-ferro

A transcrição do canto desta ave procedeu-se, a exemplo do sabiá-coleira, pelo método empírico, como pode ser visto na Fig. 14.

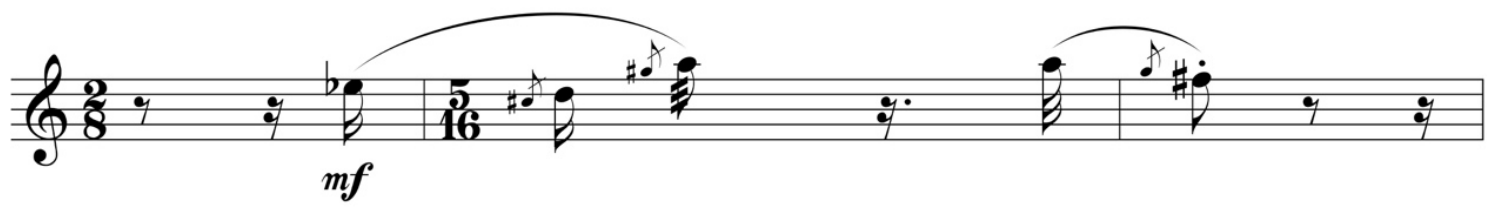

Fig. 14: Transcrição do trinca-ferro

Tal como está grafada, esta transcrição aparece em diversos momentos da peça, sendo inicialmente apresentada pelo xilofone no compasso 30 . Porém, no caso do trinca-ferro, há uma "segunda transcrição". Trata-se de uma implementação em OpenMusic na qual uma amostra do canto deste animal é submetida a uma decomposição de FFT que separa a frequência fundamental para assim gerar uma curva gráfica. Esta curva é utilizada como parâmetro de controle de altura e duração. O resultado é uma espécie de time stretch, ou dilatação do tempo conjuntamente com uma compressão de altura. $\mathrm{Na}$ prática, as alturas foram limitadas entre uma extensão predefinida e o tempo estriado em subdivisões regulares durante uma escala de tempo maior do que a duração original da amostra.

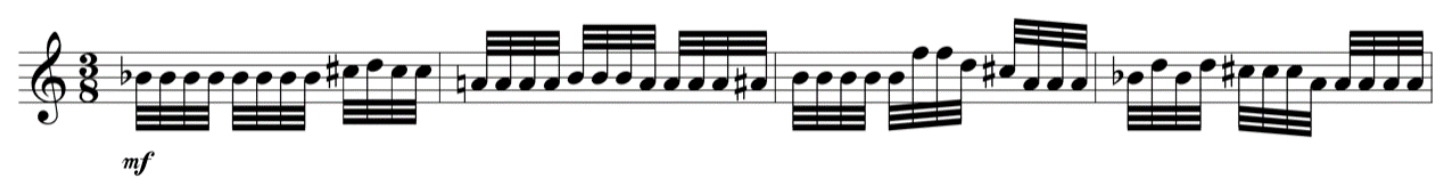

Fig. 15: Releitura do trinca-ferro ao xilofone, compassos 79-82

Na Fig. 15 vê-se o início do resultado do processamento realizado em OpenMusic. Nesta passagem as figuras de menor duração, fusas, aparecem em substituição às semicolcheias por motivos de adequação à leitura/escrita instrumental, como foi dito 
no início. A ideia de uma figura mínima de pulso permanece a mesma, entretanto o que se procura estabelecer ao longo de toda a peça, mas aqui de maneira mais evidente, é um tipo de descontinuidade. A ideia da descontinuidade a que me refiro fundamenta-se na propriedade de constituir a forma através de elementos que não se conectam, mas, antes, demarcam uma fronteira. São os casos em que deliberadamente não há relação causal entre o elemento instante e o seguinte. Pode-se também encontrar esse mesmo conceito em vários compositores, inclusive já em Debussy, em que "muitos dos Prelúdios e Estudos, por exemplo, apresentam sucessões de ideias musicais autônomas e não desenvolvimentistas que muitas vezes têm pouca semelhança com as formas tradicionais ${ }^{23 "}$ (WHEELDON, 2004, p.101, tradução minha). A partir desse prolegômeno do descontínuo, que se estabelece em Debussy, a justaposição de ideias resultará nas formas engendradas por George Crumb ao longo dos dois primeiros volumes de Makrokosmos. Neste, o compositor, que declaradamente reconhece a influência de Debussy, trata de estabelecer relações de interrupção e não linearidade, do ponto de vista temporal. Este tipo de raciocínio formal é determinante para a minha composição, a minha música consiste neste tipo de descontinuidade.

A ideia do corte é importante também porque, ao alterar a ordem lógica dos eventos, pode tanto operar uma simples interrupção quanto pode instaurar outra dimensão de temporalidade.

É o corte que quebra o rumo das coisas e dá nascimento ao tempo [...] O que estou chamando aqui de tempo é tempo musical, tempo de escuta, e não tem nada a ver com tempo para as ciências, para os relógios ou mesmo para a filosofia. (FERRAZ, 2007, p.81).

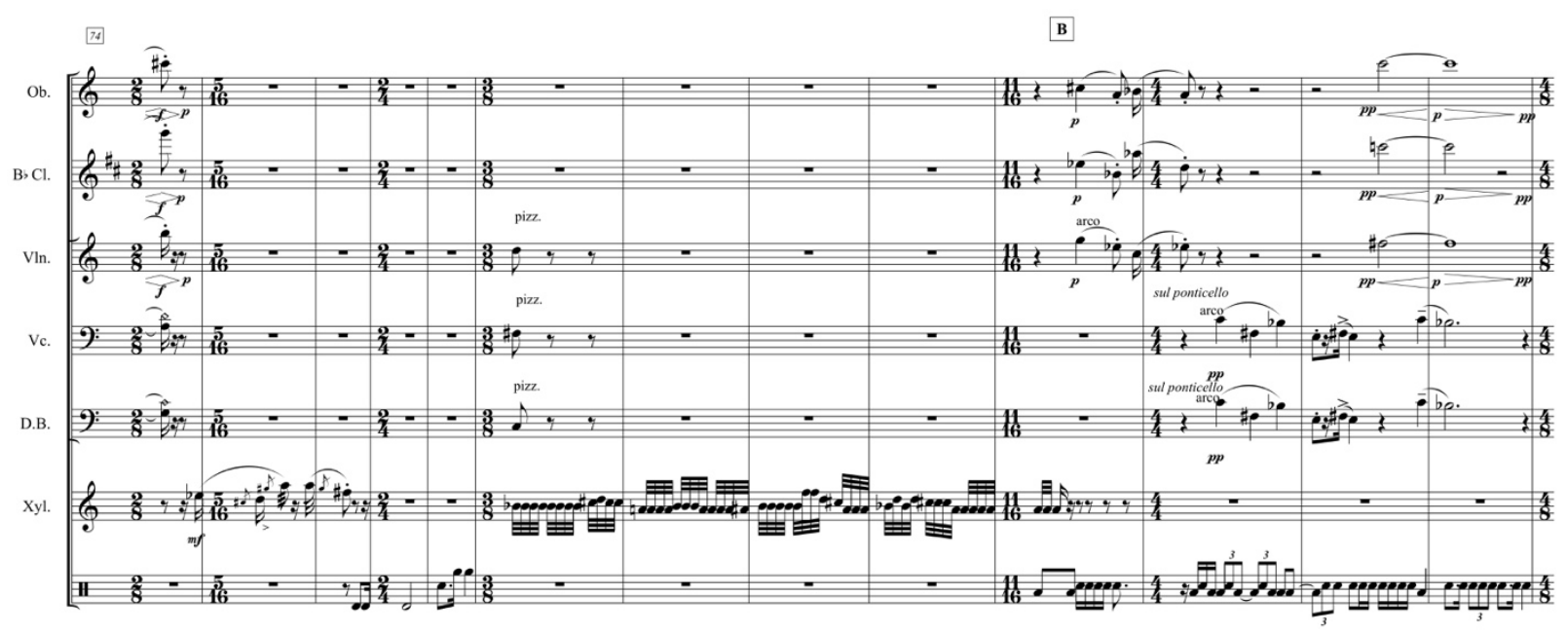

Fig. 16: Os pássaros do Delta, compassos 18-20 (orquestração do sabiá-coleira) 
É assim que, tal como em George Crumb se estabelecem vários tempos de escuta, a na justaposição de materiais sem qualquer conexão - e muitas vezes reforçada por uma pausa - instala-se a sensação de um deslocamento temporal.

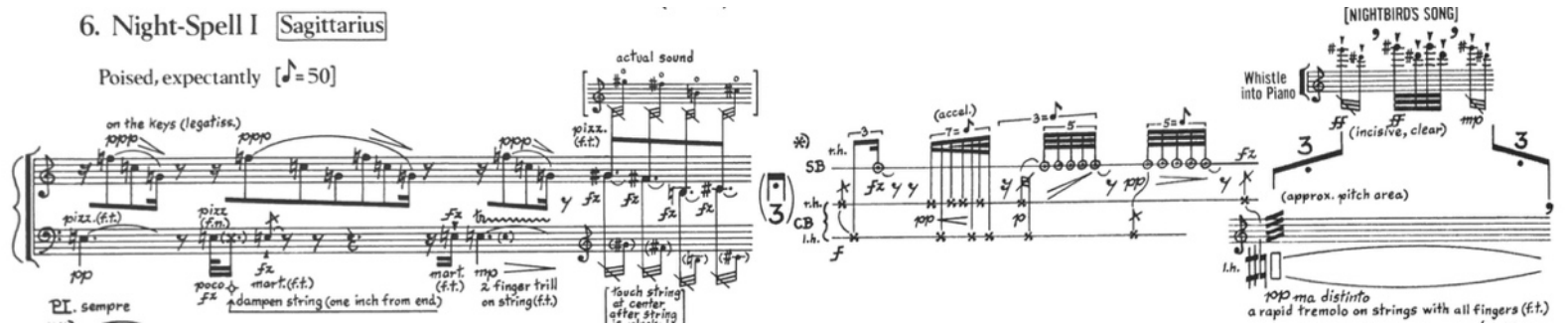

Fig. 17: George Crumb, trecho inicial de Night Spell - Makrokosmos I n 6

Além da questão do tempo, a não conectividade entre as partes implica a descontinuidade de ideias, que podem ou não ser retomadas. No caso de Messiaen, é possível pensar numa estrutura que se vale tanto da repetição quanto da interrupção.

Uma característica notável da Turangalila-Symphony é a riqueza e a variedade de seu material musical. Apesar da repetição e transformação sistemáticas de seu material principal, os métodos característicos de trabalho de Messiaen criam um tipo de estrutura que depende do princípio da colagem, e não dos métodos tradicionais da sinfonia. (JOHNSON, 1975, p.114, tradução minha) ${ }^{24}$.

Na Fig. 18 é visto como os vários elementos são justapostos sem qualquer transição entre eles. São como pássaros de espécies distintas que se intercalam, mas não interagem uns com os outros, a não ser pelo fato de que partilham do mesmo bioma. É como no exemplo da Fig. 18, extraído de Oiseaux Éxotiques; os pássaros estão sobrepostos, que é de fato a coesão entre os elementos.

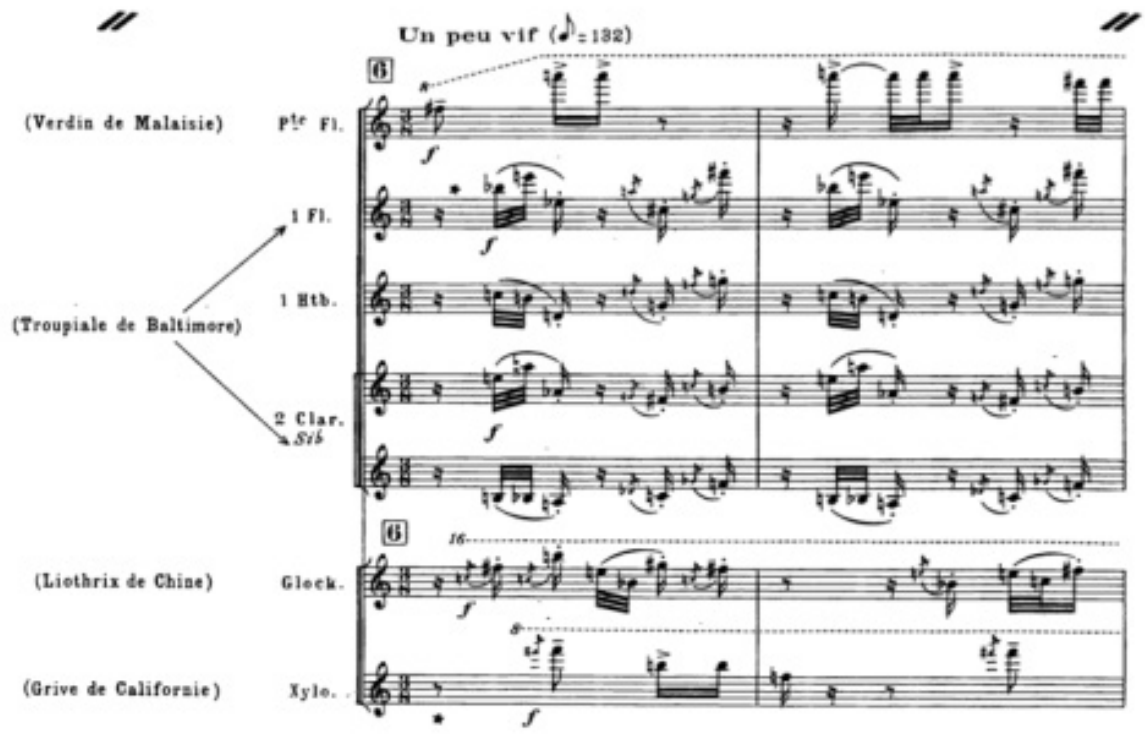

Figura 18: Oiseaux Exotiques

24 Original: "A notable feature of Turangalila-Symphony is the wealth and variety of its musical material. In spite of the systematic repetition and transformation of its principal material, Messiaen's characteristic methods of working create a type of structure which depends on the principle of the collage rather than traditional symphonic methods" (JOHNSON, 1975, p.114). 
Uma maneira interessante para se pensar a descontinuidade é o conceito de figura e fundo, no qual o jogo de permanência e desaparição propicia o delinear de um objeto. Há que se notar, tal como Rossetti faz acertadamente, que os elementos não são marcados em definitivo como figura ou fundo, são móveis. Por esse motivo, a instabilidade é, na realidade, a força motriz da ação.

A percepção da forma está diretamente relacionada à capacidade do receptor de apreender a informação transmitida. Por vezes elementos figurativos (fala ou melodia) são levados a ser percebidos como fundo, momentos nos quais explicitamente há uma dificuldade de compreensão da informação transmitida. Um ruído de fundo, menos carregado de informação, pode causar o mascaramento de algumas estruturas sonoras. (ROSSETTI, 2016, p.104).

No caso específico da peça Os pássaros do Delta, as descontinuidades são mais facilmente delimitadas porque operam, via de regra, por justaposição. Apesar de haver um fluxo rítmico (que é mantido pelas semicolcheias), o sentido formal desta peça é orientado pela disrupção. Se não houvesse esse fluir do ritmo no tempo, grande parte dessa peça se tornar-se-ia uma sucessão de cortes de um personagem a outro, visto que, dentre os processos de escrita que empreendi, se destaca o "comentário". Sobre essa técnica, Messiaen descreve como sendo um tipo de desenvolvimento melódico em que alguns fragmentos do tema são repetidos. Porém, devido à força dos elementos contrastantes em oposição, o comentário não é capaz de ligar duas ideias. Isto porque, mesmo que se faça a inclusão das diferentes formas de diminuição rítmica, e demais operações, o personagem ainda possui sua identidade (Fig. 18).

Os personagens melódicos permitem uma grande flexibilidade, que é necessá-
ria para serem combinados com os outros tipos de personagens. Isso sugeriria
uma aplicação de terminologia diferente à mesma técnica, e também revelaria a
influência de Stravinsky a ser rastreada até antes da Sinfonia Turangalila. A técni-
ca de personagens melódicos destaca como Messiaen reconstitui um processo
observado na obra de Stravinsky e não apenas o usou em sua própria música,
mas também desenvolveu seu potencial. (HEALEY, 2013, p.94, tradução minha).

Mesmo em face da "grande flexibilidade" que o personagem comporta, o limite desta resiliência é justamente a sua assimilação como indivíduo.

Dentre todos os personagens, procurei estabelecer um que possuísse uma curva predominantemente melódica - ainda que o caráter homofônico sugira que este personagem seja uma entidade harmônica, que sem dúvida também se verifica. Mas a estrutura foi pensada, antes de tudo, como um personagem melódico (que se apresenta no violoncelo). 


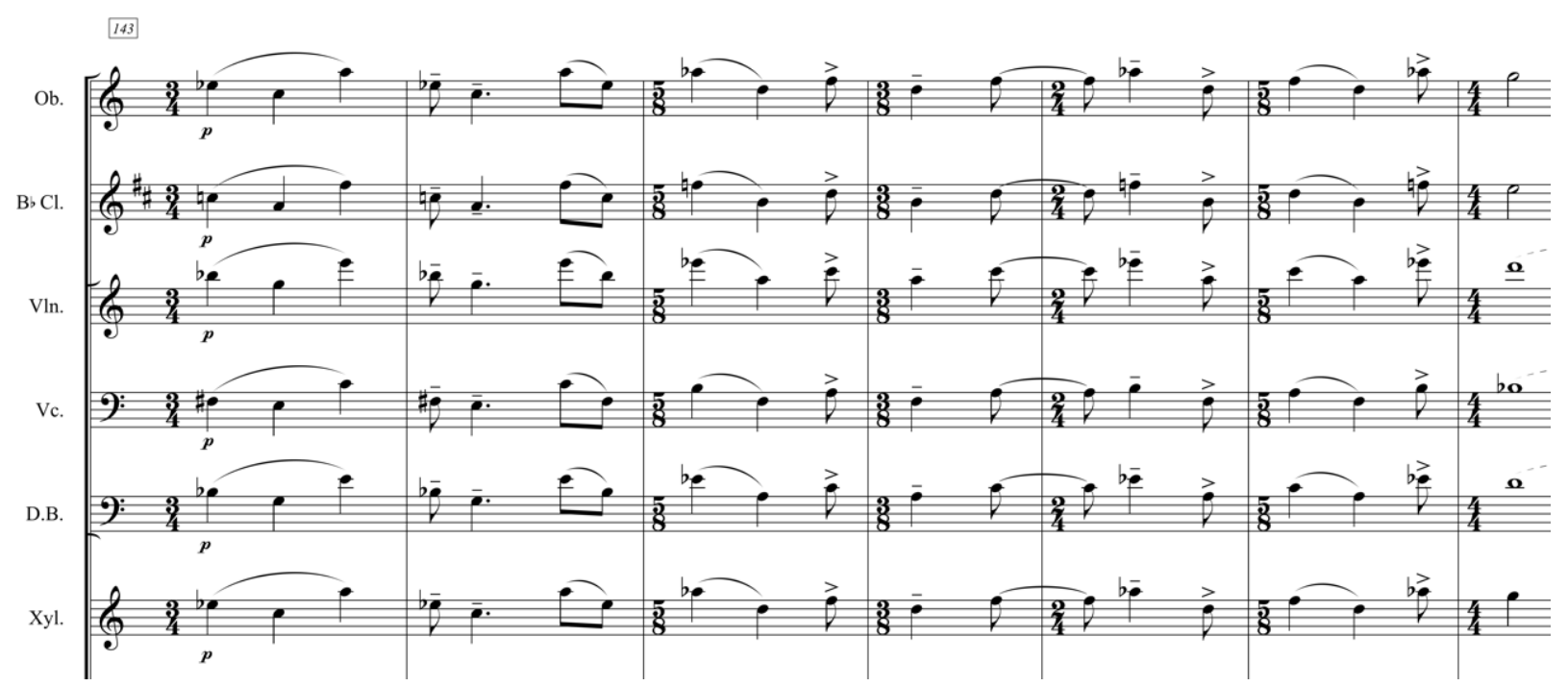

Fig. 19: Os pássaros do Delta, compassos 143-146, exemplo de personagem harmônico

Para a construção, no sentido vertical, utilizei o raciocínio de compor o timbre como se fosse a registração de um órgão - com mais liberdade, é claro. A transcrição em alturas reais do compasso143 pode ser vista na Fig. 20.

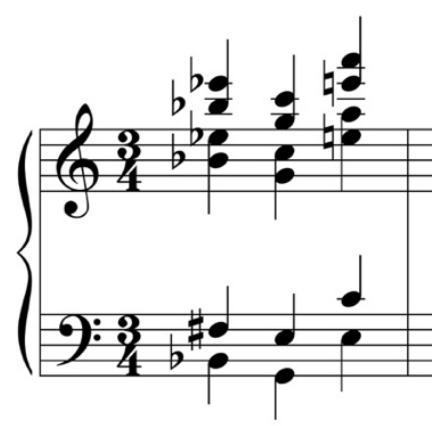

Fig. 20: Transcrição do compasso 143 em alturas reais

Do ponto de vista rítmico, usei a uma elaboração por diminuição e aumentação de colcheias a partir de uma métrica regular inicialmente estabelecida como sendo ternária. Cada bloco corresponde a uma nova estrutura. O primeiro bloco inicia-se no compasso 115 e vai até o compasso 120; o segundo bloco começa no compasso 121 e se estende até o compasso 130, após o qual há uma descontinuidade. $O$ terceiro bloco tem início no compasso 143 e termina no compasso 149 . O penúltimo bloco de personagens vai do compasso 193 (após uma pausa geral) até o compasso 196, e, por fim, o último bloco - com o solo do violoncelo -, do compasso 197 ao compasso 203.

\section{Conclusão}

Após essas explanações, está declarado que a base do meu processo de composição para essa peça foi fundamentada em Olivier Messiaen, George Crumb e Silvio Ferraz. Não vejo motivo algum para negar esse fato, pelo contrário, considero isso importante para a formação de um compositor. Além do mais, todo compositor deve dominar a sua técnica sem medo de comparações, por mais cruéis que estas possam ser. 
Quanto ao uso dos aparatos tecnológicos, estes têm sido parte integrante tanto da minha pesquisa quanto da minha prática composicional, e, como tal, participam de maneiras distintas e em maior ou menor grau, a depender das particularidades da composição de cada obra. No caso específico da peça tratada ao longo deste artigo, o escopo da aplicação computacional limitou-se a gerar materiais de duas maneiras. A primeira foi feita ao analisar uma amostra sonora e extrair um perfil melódico, que por sua vez foi grafado em alturas e durações. A segunda, através do Orchids, ao analisar outras amostras pelo critério de centroide espectral, de modo a gerar diferentes opções de escrita instrumental já codificadas em altura, duração, intensidade, e ainda aspectos próprios da execução de cada instrumento. O uso desta ferramenta específica resultou efetivo até certo ponto; sua maior contribuição está mais na capacidade de gerar situações sonoras inusitadas do que propriamente em retornar à semelhança do som original. Durante a fase de experimentos, observei que resultados mais variados e interessantes são obtidos no contexto de grandes grupos instrumentais. Como, no caso, essa peça é escrita para um septeto - e a percussão não está disponível dentre os instrumentos a serem usados no Orchids -, a gama de possibilidades é limitada, o que de certa forma circunscreve a sonoridade ao perfil mais transparente que se apresenta na peça. Por outro lado, há uma gama imensa de possibilidades instrumentais que pode ser explorada, principalmente no âmbito das técnicas estendidas, que o Orchids não desvela. Porém, foi interessante usar o material gerado por este programa no sentido de estudar as relações técnicas individuais dos instrumentos, suas relações em grupo, e seu resultado sonoro completo, que contribuiu para despertar novas e inusitadas soluções texturais.

Concebo os processos composicionais como sendo a maneira de elaborar os materiais por meio de uma mistura de invenção e apropriação de ferramentas dentro da atividade de criação. Algumas vezes inventamos uma ferramenta para compor, outras inventamos a composição a partir de uma ferramenta já existente. Ideias, conceitos, leituras e releituras, tudo isso é parte do universo do compositor. Ao descrever o processo de composição dessa determinada peça, coloquei em perspectiva as minhas próprias interpretações. Muito além da técnica, do manuseio do ferramental, considero que criar implica descobrir de que maneira a percepção do mundo é desenhada no plano composicional, para assim, em retrospecto, revelar a música que surge nesse ínterim na forma de som sendo propagado em espaço e tempo.

\section{Referências}

BAILLET, Jérome. Flèche du temps et processus dans les musiques après 1965. In: LÉVY, Fabien (org.). Les écritures du temps. Paris: L'Hartmattan, 2001.

BENITEZ, Vincent. Olivier Messiaen, a research and information guide. New York: Routledge, 2008.

CRUMB, George. Makrokosmos vol. I. Piano. New York: Peters, 1973. 1 Partitura. 
DE LA MOTTE, Diether. Harmonielehre. Kassel: Bärenreiter, 2009.

FALLON, Robert. Messiaen Perspectives 1: Sources and Influences. Farnham: Ashgate, 2013.

FERRAZ, Silvio. Música e Repetição. São Paulo: Sete Letras, 1998.

FERRAZ, Silvio. Notas do caderno amarelo. Campinas: Unicamp, 2007.

HERVÉ, Jean-Luc. Musique contemporaine: une solution de continuité. In: COHENJOHNSON, Robert Sherlaw. Birdsong. In: HILL, Peter (ed.). The Messiaen Companion. London: [s. n.], 1995.

LÉVINAS, Danielle (org.). La création après la musique contemporaine. Paris: L'Harmattan, 1999.

MANOURY, Philippe. L'invention de la musique. Paris: Fayard, 2017.

MESSIAEN, Olivier. Chronochromie. Paris: Alphonse Leduc, 1960.

MESSIAEN, Olivier; WATTS, Harriett. Canyons, Colours and Birds: An Interview with Olivier Messiaen. Tempo, Mar., 1979, New Series, No. 128 (Mar., 1979), pp. 2-8

MOREIRA, Adriana. Olivier Messiaen: inter-relação entre conjuntos, textura, rítmica e movimento em peças para piano. Tese (Doutorado) - Programa de Pós-Graduação em Música, Universidade Estadual de Campinas, Campinas, 2008.

ROSSETTI, Danilo. Processos microtemporais de criação sonora, percepção e modulação de forma: uma abordagem analítica e composicional. Tese (Doutorado) - Programa de Pós-Graduação em Música, Universidade Estadual de Campinas, Campinas, 2016.

SOUVTCHINSKY, Pierre. Igor Stravinsky, la notion du temps et la musique. Revue Musicale, Paris, v. 20, n. 191, p. 70-80, 1939.

STOÏANOVA, Ivanka. Geste, texte, musique. Paris: Union Général d’Editions, 1975.

TREMBLAY, Giles. Oiseau-nature, Messiaen, musique. Cahiers canadiens de musique (Spring-Summer 1970): p.15-40 